\title{
QUALITY OF RUNOFF FROM SMALL WATERSHEDS IN THE TWIN CITIES METROPOLITAN AREA, MINNESOTA- A PROJECT PLAN
}

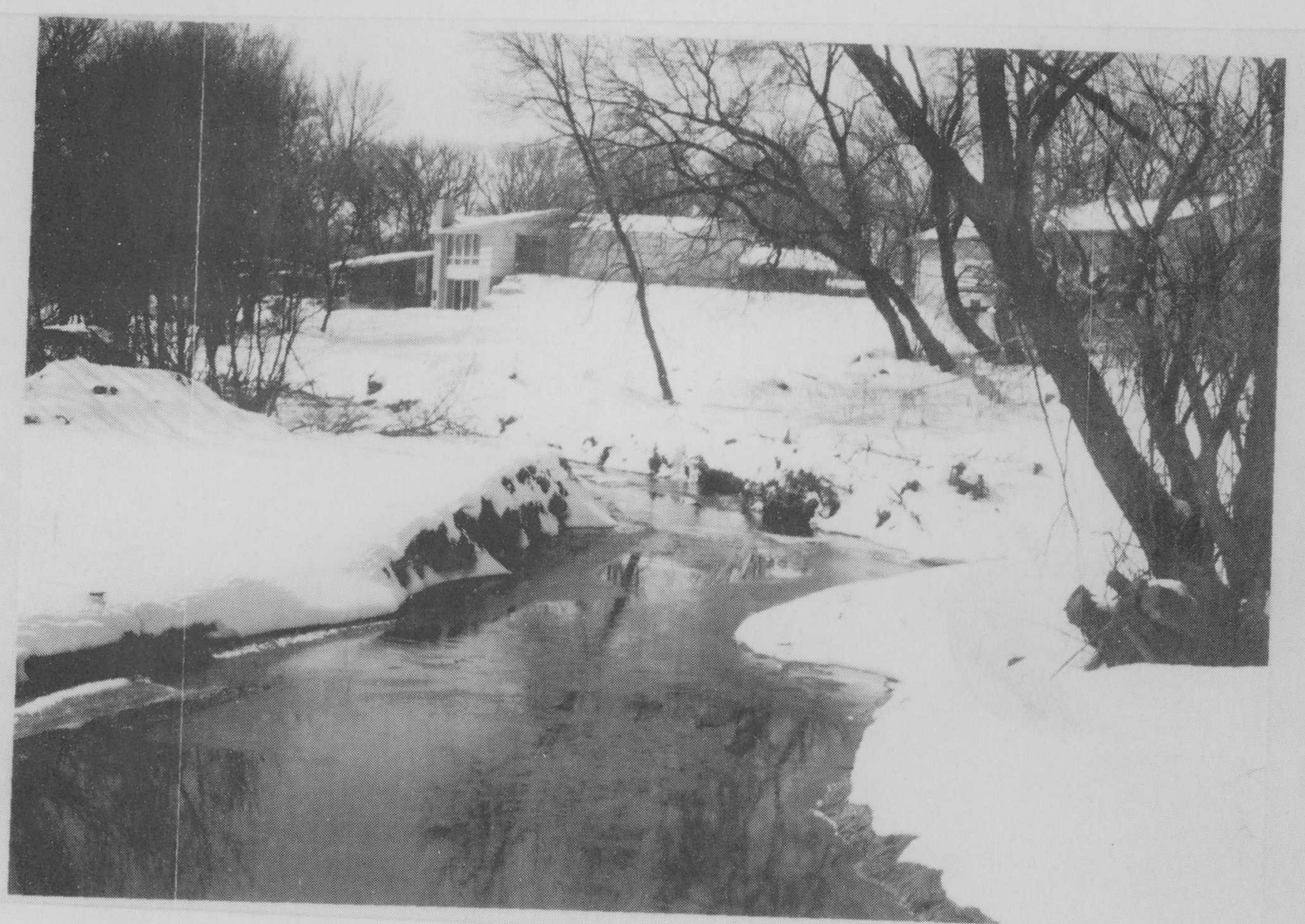

U. S. GEOLOGICAL SURVEY

Open-File Report 80-592

Prepared in cooperation with the Metropolitan Council of the Twin Cities

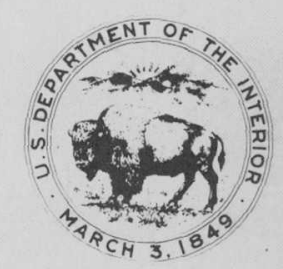




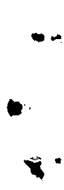

Housing along Bassett Creek upstream of County Road 66 (Golden Valley Road) gaging and sampling site. 
UNITED STATES

DEPARTTENT OF THE INTERIOR

GEOLOGICAL SURVEY

QUALITY OF RUNOFF FROM SMALL WATERSHEDS IN

THE TWIN CITIES MEIROPOLITAN AREA, MINNESOTA--

A PROJECT PLAN

By M. A. Ayers, G. A. Payne, and G. L. Oberts

Open-File Report 80-592

Prepared in cooperation with the

Metropolitan Council of the Twin Cities

St. Paul, Minnesota

1980 
$\infty$

$\checkmark$ 
Page

Conversion factors................................... IV

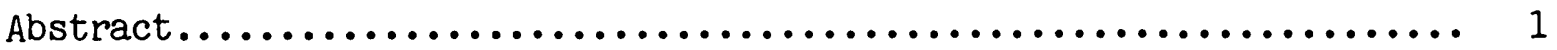

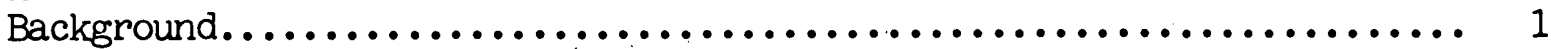

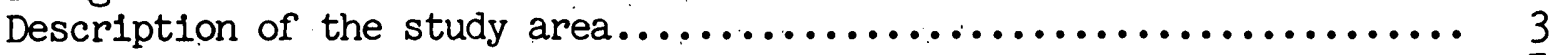

Objectives......................................... 7

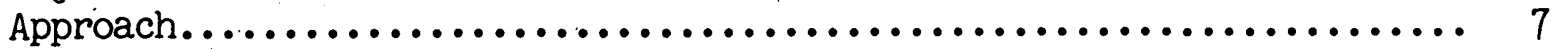

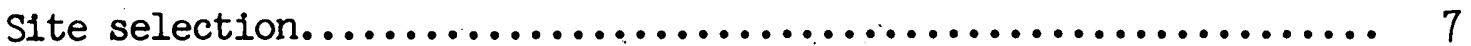

Data collection and instrumentation...................... 12

Laboratory analyses.................................. 12

Quality-assurance program............................. 23

Data management and analyses........................... 24

Final products..................................... 29

Time schedule...................................... 29

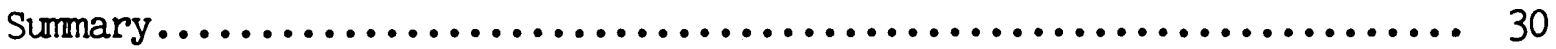

References............................................ 31

ILLUSTRATIONS

Figure 1. Map showing study location and subwatersheds consistently

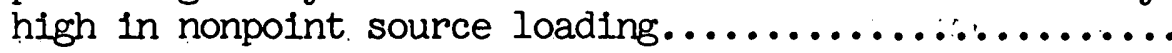

2. Map showing generalized land use for Twin Cities

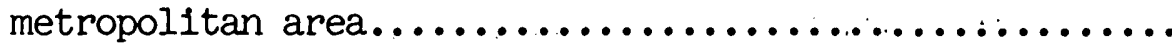

3. Map showing geomorphic regions of the Twin Cities

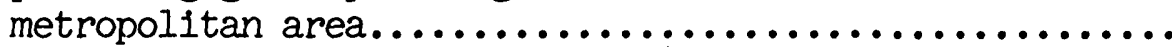

4. Map showing location of munoff and rain quality sampling sites.................................... 8

5. Diagram of an assembled monitoring station............ 15

6-12. Photographs of equipment to be used in the study:

6. Estates Drive gage typical of the seven storm sewer installations.............................. 16

7. Looking upstream at a typical storm-sewer flume

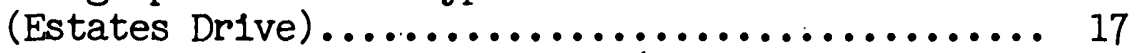

8. Inside a typical gaging shelter (tipping bucket rain sensor on roof $) \ldots \ldots \ldots \ldots \ldots \ldots \ldots \ldots \ldots \ldots 18$

9. 80th Street storm-sewer gage automated for stage

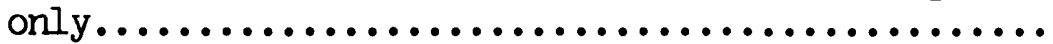

10. Elm Creek gage typical of three agricultural and two urban main stem installations, automated for stage and water-sample collection.............. 


\section{ILUUSTRATIONS}

Flgures 6-12. Photographs of equipment to be used in the study--

Continued:

11. Credit River gage typical of three agricultural main stem installations automated for stage

only............................... 21

12. Bevins Creek automatic wet/dry precipitation installation located with bulk and tipping bucket rain gages in this case............. 22

13. Flow chart of data-management processes............ 28

TABLES

Table 1. Comparison of average annual pollutant loads from point and nonpoint sources in the Twin Cities metropolitan area..... 2

2. Characteristics of agricultural and urban watersheds being sampled in the study............................ 9

3. Frequency of analyses of runoff samples................ 13

4. Generalized laboratory schedules..................... 14

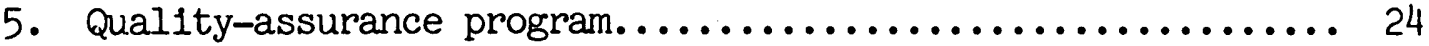

6. List of potential variables to be used in correlation and regression analyses............................ 26

\section{CONVERSION FACTORS}

Multiply

Inch-pound units

inch (in)

foot ( $\mathrm{ft}$ )

mile (mi)

square mile $\left(\mathrm{mi}^{2}\right)$
By

25.40

0.3048

1.609

2.590
To obtain SI units

millimeter (mm)

meter (m)

kilometer $(\mathrm{km})$

square kilometer $\left(\mathrm{km}^{2}\right)$

National Geodetic Vertical Datum of 1929 (NGVD of 1929).

A geodetic datum derived from a general adjustment of the first order level nets of both the United States and Canada, formerly called "mean sea level". The datum was derived from the average sea level over a period of many years at 26 tide stations along the Atlantic, Gulf of Mexico, and Pacific Coasts. 
QUALITY OF RUNOFF FROM SMALL WATERSHEDS IN

THE TWIN CITIES METROPOLITAN AREA, MINNESOTA--

A PROJECT PLAN

By Mark A. Ayers, Gregory A. Payne, and Gary L. Oberts

\begin{abstract}
A program of water-quality sampling to define the relationships between land use, watershed characteristics, and the quantity, quality, and timing of munoff has been started for the Twin Cities metropolitan area of Minnesota. Ten major watersheds were chosen as representative of conditions in the metropolitan area. Each will be sampled at one location near the outlet. Six of the watersheds are agricultural and range in size from 14.3 to 82.9 square miles. The four remaining watersheds are urbanized and range in size from 1.22 to 31.7 square miles. In addition, seven urban subwatersheds, which range in size from 0.12 to 0.47 square miles and reflect a dominant land-use type, will be sampled.

Data collection is designed around the hydrologic conditions expected for each site. Sixteen of 17 sites are instrumented to define stream discharge, and 12 sites have automatic water samplers and recording rain gages. In addition, six sites will have automatic wetfall/dryfall precipitation collectors.
\end{abstract}

Samples for analysis of 32 chemical, physical, and biological constituents will be collected at varying frequencies, with emphasis on storm sampling for suspended solids and nutrients. A data-management system being designed for the U.S. Geological Survey Urban Hydrology Studies Program will facilitate data processing. Data interpretation will be aimed at defining the quantity and quality characteristics of runoff from study watersheds. These findings will be extrapolated to unsampled watersheds in the metropolitan area.

\title{
BACKGROUND
}

Studies throughout the. United States indicate that materials carried in nonpoint-source runoff contribute significantly to the degradation of streamwater quality (Federal Water Pollution Control Administration, 1969; Lager and Smith, 1974; Sliter, 1976; Bradford, 1977; Sonzogni and others, 1980). However, the amount of materials delivered by individual basins varies considerably from one area to another and from storm to storm within an area (McElroy and others, 1976; Sonzogni and others, 1980), indicating a need for local data. 
Preliminary estimates of the average annual nonpoint-source loads of various constituents (in tons per year) in the Twin Cities metropolitan area (fig. 1) have been made through the local PL92-500 section 208 study (Oberts and Jouseau, 1979). These estimates are based on literature values of constituent concentrations for various land-use categories and on estimates of discharge. The estimates indicate that annual loads of chemical-oxygen demand, suspended solids, nitrate, lead, and zinc from nonpoint sources probably equals or exceeds the annual point-source loads of the metropolitan area (table 1). Drainage basins suspected of being source areas for the most serious nonpoint problems have been identified (fig. 1). The 208 Phase I study established that a water-quality study of nonpoint-source munoff from representative urban and agricultural watersheds in the metropolitan area is needed to define the relationships between land use, watershed characteristics, and the quantity, quality, and timing of runoff.

Table 1.--Comparison of average annual pollutant loads from point and nonpoint sources in the Twin Cities metropolitan area

[from Oberts and Jouseau, 1979]

\begin{tabular}{|c|c|c|c|}
\hline \multirow{2}{*}{. } & $\begin{array}{c}\text { Nonpoint sources } \\
\text { (tons per year) }\end{array}$ & \multicolumn{2}{|c|}{$\begin{array}{l}\text { Point sources } \\
\text { (tons per year for 1976) } \\
\end{array}$} \\
\hline & . & $\begin{array}{c}\text { Sewage treatment } \\
\text { plants }\end{array}$ & Industries \\
\hline $\begin{array}{l}\text { Biochemical-oxygen } \\
\text { demand............. }\end{array}$ & 6,869 & 20,900 & 703 \\
\hline $\begin{array}{l}\text { Chemical_oxygen } \\
\text { demand............. }\end{array}$ & 42,046 & 64,013 & 3,209 \\
\hline $\begin{array}{l}\text { Total suspended } \\
\text { solids............ }\end{array}$ & 172,559 & 18,845 & 1,139 \\
\hline Total phosphorus...... & 221 & 1,568 & 2.2 \\
\hline Nitrate-nitrite....... & 239 & 232 & - \\
\hline Ammonia nitrogen...... & 354 & 4,504 & - \\
\hline Kjeldahl nitrogen..... & 863 & 5,771 & - \\
\hline Chromium............. & 23 & 102 & 9.3 \\
\hline Copper.............. & 21 & 36 & - \\
\hline Lead................. & 101 & 30 & 0.32 \\
\hline 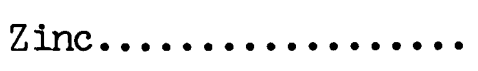 & 59 & 54 & 3.8 \\
\hline
\end{tabular}


The study area encompasses about $3,000 \mathrm{mi}^{2}$ of the Twin Cities metropolitan area [Anoka, Carver, Dakota, Hennepin, Ramsey, Scott, and Washington Counties (fig. 1)], but does not include the combined sewered areas of Minneapolis, St. Paul, and South St. Paul, which are being studied by the MWCC (Metropolitan Waste Control Commission) under a Section 201 Facilities Planning grant. The population of the metro area is about 2,000,000, with the largest concentration in the central cities at a density of 22,000 people per square mile.

Land use in the metro area is 43 percent agricultural, 27 percent urban, and 30 percent open space (Oberts and Jouseau, 1979). Urban growth 1s concentrated around the Minneapolis and St. Paul metropolitan centers, with the most growth to the north, south, and west (fig. 2). The major agricultural areas are to the south and west in Dakota, Scott, and Carver Counties.

The topography is characterized by gently undulating, glaciated uplands dissected by the Mississippi, Minnesota, and St. Croix River valleys (fig. 3 ). The total relief is about 600 feet, ranging in altitude from less than 700 feet along the lower river reaches to more than 1,200 feet in northeastern Washington County.

The Eastern Highlands (fig. 3) is a part of the St. Croix terminal moraine. The area has well-drained loamy soils underlain by till. Drainage patterns are poorly defined, and many lakes and wetlands occur in depressions in the moraine area. The Southern and Western Highlands (fig. 3) are also moraine areas of well-drained loamy soils, but drainage patterns are better defined than in the Eastern Highlands, and the solls are better suited for agriculture. Many lakes and wetlands occur in depressions or as components of the stream systems.

Alluvial deposits are generally characterized by sandy, well-drained soils. The Mississippi Valley alluvium in Dakota County is particularly well suited to intensive farming with the aid of irrigation. Flood-plain soils are generally poorly drained.

The northern part of the metropolitan area is characterized by flatlying outwash deposits of the Anoka Sand Plain (fig. 3). The fine, sandy solls are generally well drained, but a high water table has caused many marshes, peatbogs, and shallow lakes. Sod and vegetable farns are common.

The climate is one of generally mild, humid summers and relatively long, severe winters. Normal annual precipitation is 27 inches, with 44 inches of snow in the winter. May and June are generally the wettest months and February the driest. Most rain comes as frontal storms and some as warmweather convective storms. 

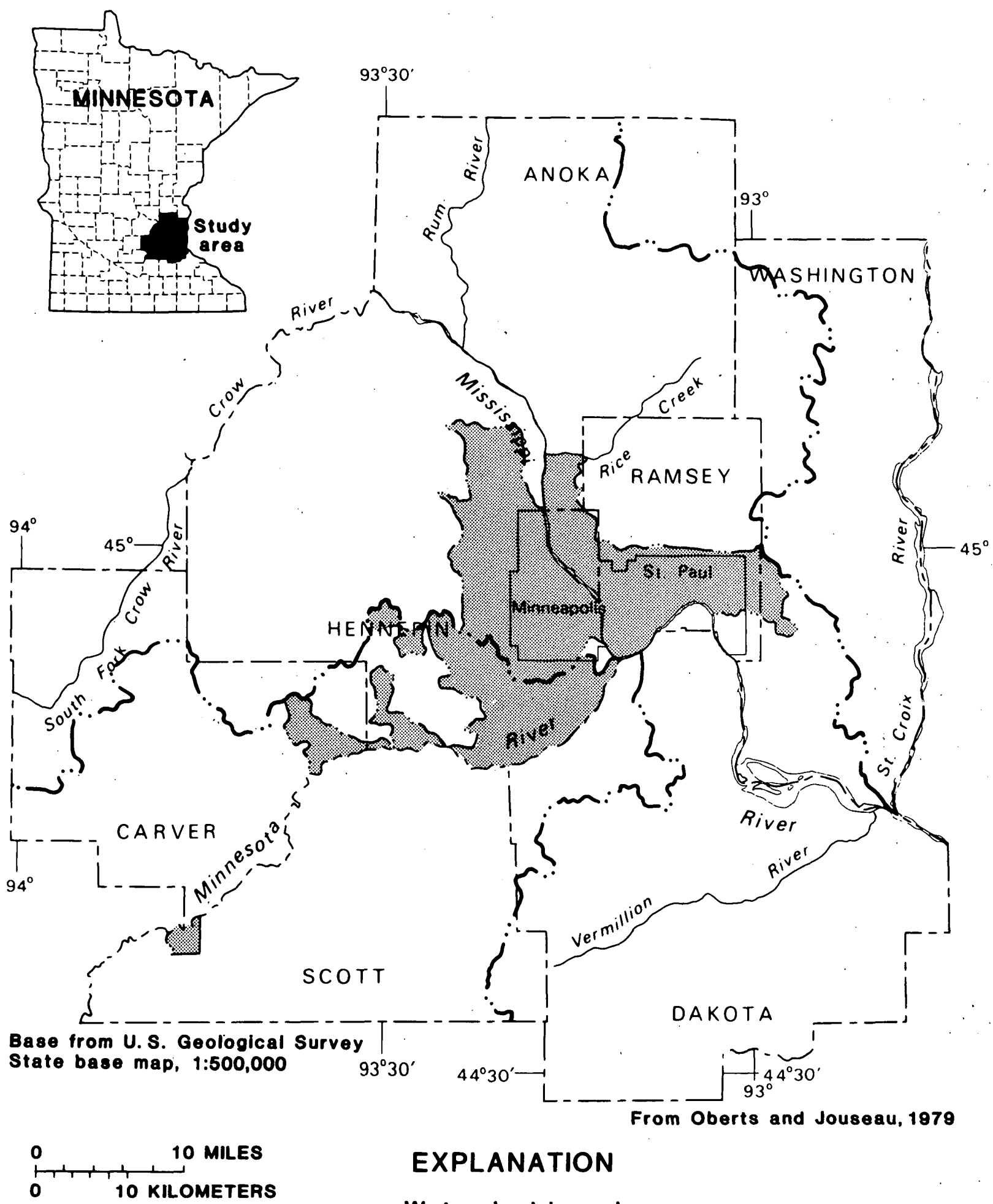

EXPLANATION

Watershed boundary

Subwatershed boundary

High urban nonpoint loading

Flgure 1.--Location map and subwatersheds consistently high in urban nonpolnt source loading 


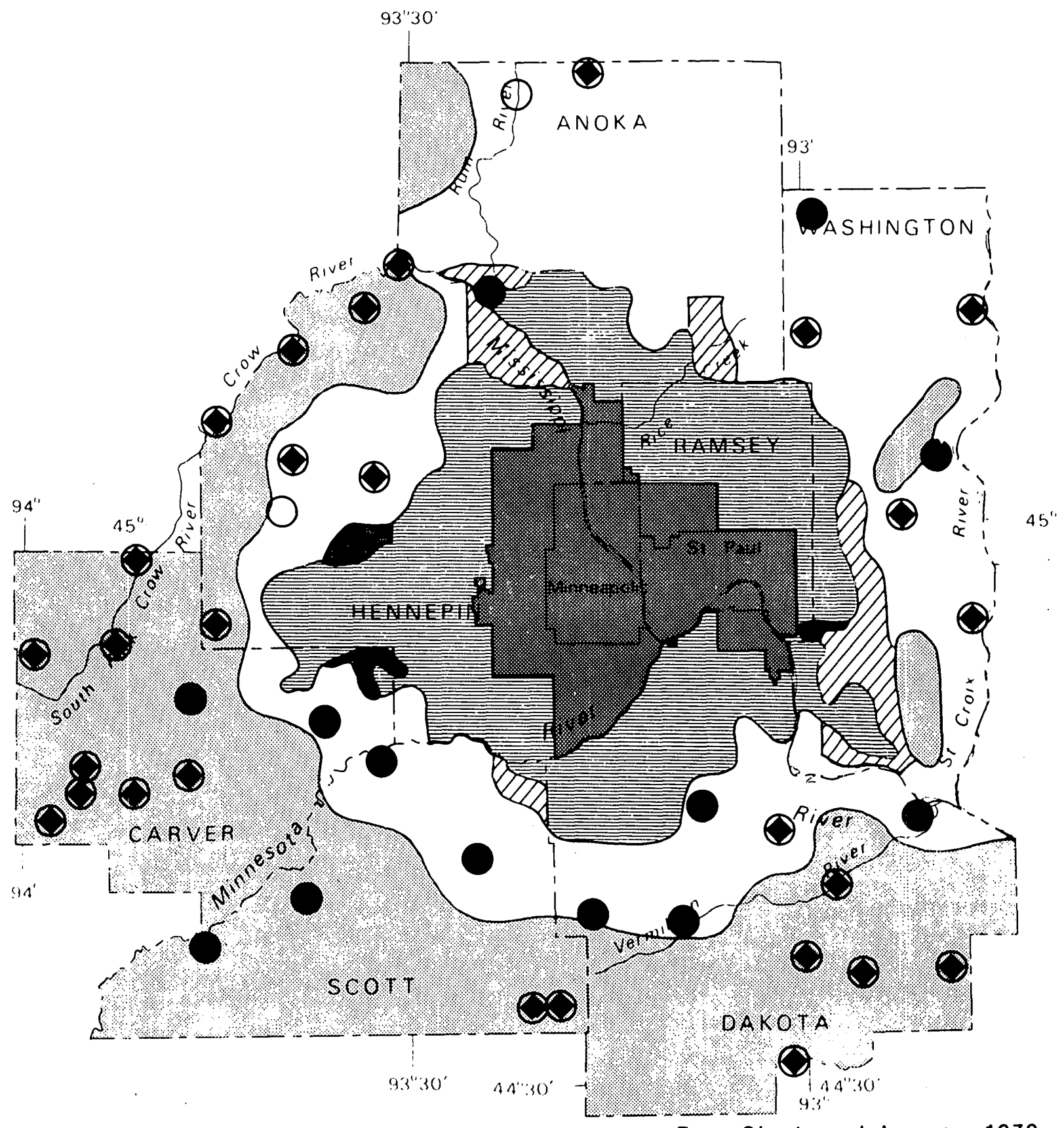

From Oberts and Jouseau, 1979

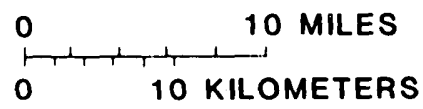

\section{EXPLANATION}

$\because$

Fully developed area

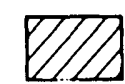

Addition, 1981-1990

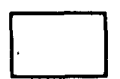

General rural use region

Planned

urbanization, 1975

Addition, 1976-1980

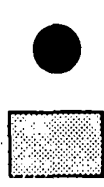

Freestanding growth center Commercial agriculture region $\theta$ Rural center

Proposed growth center

Figure 2.--Generalized land use for Twin Cities metropolitan area 


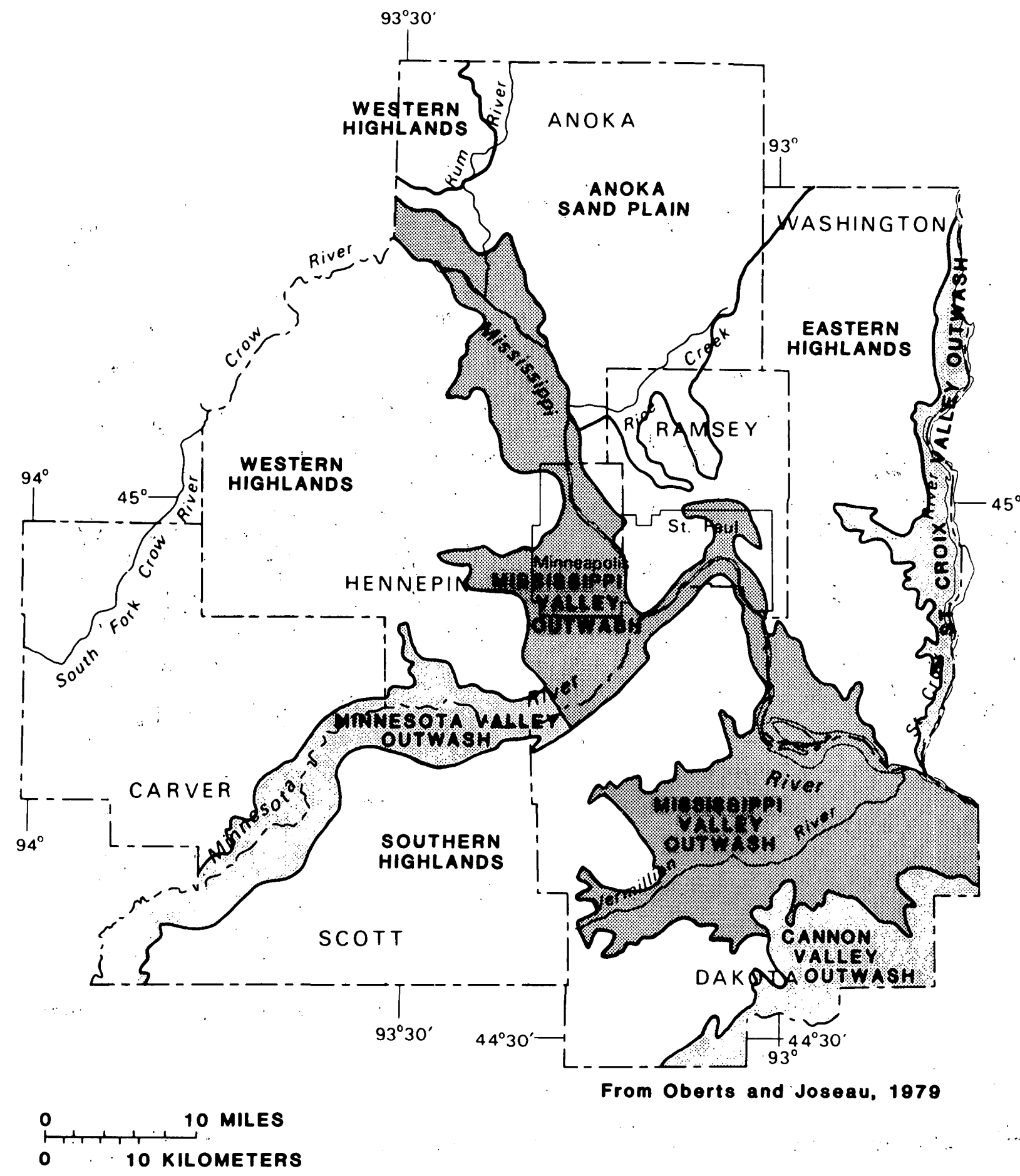

Flgure 3.-- Geomorphlc reglons of the Twin Citles metropolitan area 


\section{OBJECTIVES}

The objectives of this study are to (1) quantify and characterize storm and annual nonpoint-source loads for representative watersheds, (2) provide information on transport mechanisms of problematic water-quality constituents, and (3) develop a method to estimate storm and annual water-quality loadings from unsampled watersheds. The results of this study will provide better definition of the relationships between land use, watershed characteristics, and the quantity, quality, and timing of runoff, so that effective action to correct nonpoint-source-related problems can be identified by the Metropolitan Council of the Twin Cities.

\section{APPROACH}

\section{Site Selection}

Selection of urban and agricultural sites for the study was completed in November 1979. Numerous meetings and telephone conversations with city engineers and planners, soll and water conservation district personnel, and county and state highway engineers, together with extensive field reconnaissance were necessary for selection of data collection sites. The criteria utilized for this task included:

1. watersheds that were representative of the metropolitan area in terms of land use, soils, basin slope, channel or storm-sewer design, and hydrologic characteristics such as wetlands and lakes,

2. sites where accurate flow data could be obtained, and in the case of urban subwatersheds, sites that drained directly into a major stream system rather than a lake system, and

3. areas for which no other data were available.

Six agricultural and four urban watersheds were selected. Main stem monitoring sites were chosen for each, and, in the four urban areas, one or more storm-sewered-subwatershed sites were also selected. This nested design of urban watersheds was to ald in calibration of load-estimation procedures to be used in the final model analysis. Two Minnesota River main stem sites were also selected; one where the river enters the metropolitan area (also a Geological Survey NASQAN site), and one near the mouth.

Table 2 summarizes the characteristics of each site selected; figure 4 shows the locations. A total of 17 runoff-data-collection sites have been chosen. Six automatic wetfall/dryfall sampling sites around the metropolitan area have been chosen (fig. 4). 


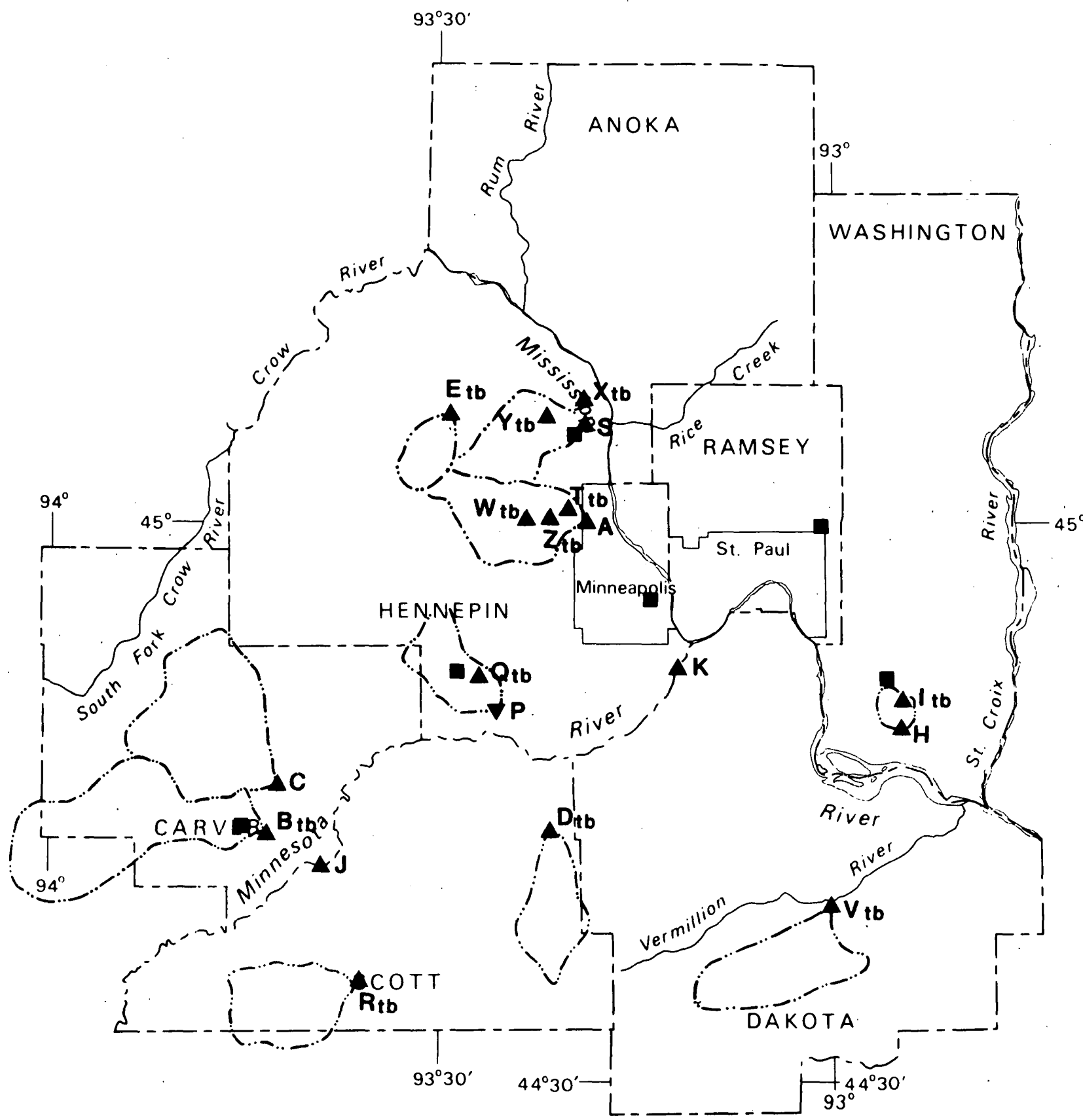

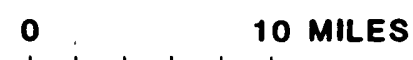

0 KILOMETERS

\section{EXPLANATION}

$\triangle$ Runoff sampling site with gage

$\nabla$ Runoff sampling site

A Site letter

to Tipping-bucket rain gage

-..- Watershed boundary

Automatic wet/dry precipitation sampler

Flgure 4.--Location of runoff and rain quallty sampling sites for Twin Citles runoff study 
Table 2.--Characteristics of agricultural and urban watersheds being sampled in the study

\begin{tabular}{|c|c|c|c|}
\hline $\begin{array}{l}\text { Site location and } \\
\text { drainage area }\end{array}$ & $\begin{array}{l}\text { Letter } \\
\text { desig- } \\
\text { nation }\end{array}$ & County & General watershed characteristics \\
\hline $\begin{array}{l}\text { Bevens Creek at } \\
\text { County Road } 41 \\
\left(82.9 \mathrm{mi}^{2}\right)\end{array}$ & B & Carver & $\begin{array}{l}\text { Over } 70 \text { percent of watershed in farms. } \\
\text { Principally dairy or feedlot operations } \\
\text { and associated cropping. Most intensive } \\
\text { agriculture in lower two-thirds of water- } \\
\text { shed. Stream free flowing or channelized } \\
\text { through lower part. Large serles of wet- } \\
\text { lands and shallow lakes in headwaters. } \\
\text { Loamy, well-drained, dark-colored solls. }\end{array}$ \\
\hline $\begin{array}{l}\text { Carver Creek at } \\
\text { County Highway } 140 \\
\quad\left(65.2 \mathrm{mi}^{2}\right)\end{array}$ & $\mathrm{C}$ & Carver & $\begin{array}{l}\text { Similar to Bevins, except for a higher } \\
\text { concentration of wetlands and lakes } \\
\text { throughout the watershed. }\end{array}$ \\
\hline $\begin{array}{l}\text { Credit River at } \\
\text { County Road } 68 \\
\quad\left(23.2 \mathrm{mi}^{2}\right)\end{array}$ & D & Scott & $\begin{array}{l}25 \text { to } 50 \text { percent of watershed in farms, } \\
\text { typically cash crops (corn-soybeans). } \\
\text { Most agriculture is in upper part with } \\
\text { more open space in lower. Considerable } \\
\text { instream wetland influence. Some lakes } \\
\text { on tributaries. Loamy, well-drained, } \\
\text { light-colored soils. }\end{array}$ \\
\hline $\begin{array}{l}\text { Elm Creek at } \\
\text { County Highway } 10 \\
\quad\left(14.3 \mathrm{mi}^{2}\right)\end{array}$ & E & Hennepin & $\begin{array}{l}\text { Under } 25 \text { percent of watershed in farms. } \\
\text { Some hobby farms and low-density residen- } \\
\text { tial. Much land awaiting urbanization. } \\
\text { Low-gradient stream with some inchannel } \\
\text { wetlands. Loamy, well-drained, light- } \\
\text { colored soils. }\end{array}$ \\
\hline $\begin{array}{l}\text { Ravens Stream at } \\
\text { County Road } 61 \\
\quad\left(32.4 \mathrm{mi}^{2}\right)\end{array}$ & $\mathrm{R}$ & Scott & $\begin{array}{l}\text { Similar to Bevins and Carver, but without } \\
\text { the lakes. Some wetlands are present } \\
\text { along the free-flowing stream systems. }\end{array}$ \\
\hline $\begin{array}{l}\text { South Fork } \\
\text { Vermillion River at } \\
\text { County Highway } 66 \\
\quad\left(30.8 \mathrm{ml}^{2}\right)\end{array}$ & V & Dakota & $\begin{array}{l}\text { Over } 70 \text { percent of watershed in farms. } \\
\text { Virtually all cash crops with some irriga- } \\
\text { tion. Few wetlands and no lakes. Chan- } \\
\text { nelized stream in upper part, and free } \\
\text { flowing in lower. Sandy, well-drained, } \\
\text { dark-colored solls. }\end{array}$ \\
\hline
\end{tabular}


Table 2.--Characteristics of agricultural and urban watersheds being sampled in the study--Continued

\begin{tabular}{|c|c|c|c|}
\hline $\begin{array}{l}\text { Site location and } \\
\text { drainage area }\end{array}$ & $\begin{array}{l}\text { Letter } \\
\text { desig- } \\
\text { nation }\end{array}$ & County & General watershed characteristics \\
\hline $\begin{array}{l}\text { Bassetts Creek at } \\
\text { County Highway } 66 \\
\quad\left(31.7 \mathrm{mi}^{2}\right)\end{array}$ & A & Hennepin & $\begin{array}{l}\text { Upper third of watershed partly developed } \\
\text { with low to medium-density residential } \\
\text { and developing. Drains into large lake. } \\
\text { Lower part fully developed with medium } \\
\text { to high-density residential, commercial, } \\
\text { and light industrial. Good use of hold } \\
\text { ing ponds in storm-sewer system. Loamy, } \\
\text { well-drained, light-colored soils. }\end{array}$ \\
\hline $\begin{array}{l}\text { Shingle Creek at } \\
\text { Noble Avenue } \\
\quad\left(22.9 \mathrm{mi}^{2}\right)\end{array}$ & $S$ & Hennepin & $\begin{array}{l}\text { Upper third of watershed partly developed } \\
\text { with low to medium-density residential and } \\
\text { developing. Drains into several lakes. } \\
\text { Lower part fully developed, medium-den- } \\
\text { sity residential with mixed commercial. } \\
\text { Storm sewers drain directly into creek. } \\
\text { Well-drained soils, loamy, light-colored } \\
\text { in upper part and sandy, dark-colored in } \\
\text { lower. }\end{array}$ \\
\hline $\begin{array}{l}\text { Purgatory Creek } \\
\text { below Staring Lake } \\
\quad\left(24.0 \mathrm{mi}^{2}\right)\end{array}$ & $\mathrm{P}$ & Hennepin & $\begin{array}{l}\text { Partly urbanized in the upper part of the } \\
\text { watershed. Rapid urbanization occurring } \\
\text { in the middle and lower parts of the } \\
\text { watershed. Lakes common, wetlands and } \\
\text { open areas plentiful, especially along } \\
\text { the channel system. Holding ponds common } \\
\text { in existing storm sewer systems. Loamy, } \\
\text { well-drained, light-colored soils. }\end{array}$ \\
\hline $\begin{array}{l}80 \text { th } \text { Street } \\
\text { storm sewer } \\
\left(1.55 \mathrm{mi}^{2}\right)\end{array}$ & $\mathrm{H}$ & Washington & $\begin{array}{l}\text { Fully developed medium-density residen- } \\
\text { tial } 1 \text { to } 10 \text { years old. Watershed storm- } \\
\text { sewered with } 2 \text { wet and } 6 \text { dry inline hold- } \\
\text { ing ponds. Well-drained soils grade from } \\
\text { loamy, dark colored in upper end of water- } \\
\text { shed to sandy, light colored in lower. }\end{array}$ \\
\hline $\begin{array}{l}\text { Estates Drive } \\
\text { storm sewer } \\
\quad\left(0.22 \mathrm{mi}^{2}\right)\end{array}$ & $\mathrm{X}$ & Hennepin & $\begin{array}{l}\text { Medium to high-density single-family res- } \\
\text { idential area } 1 \text { to } 20 \text { years old. Storm } \\
\text { sewered with curb and gutters. Flat with } \\
\text { sandy soils. }\end{array}$ \\
\hline
\end{tabular}


Table 2.--Characteristics of agricultural and urban watersheds being sampled in the study--Continued

\begin{tabular}{|c|c|c|c|}
\hline $\begin{array}{l}\text { ite location and } \\
\text { drainage area }\end{array}$ & $\begin{array}{l}\text { Letter } \\
\text { desig- } \\
\text { nation }\end{array}$ & County & General watershed characteristics \\
\hline $\begin{array}{l}\text { Yates Avenue } \\
\text { storm sewer } \\
\quad\left(0.35 \mathrm{mi}^{2}\right)\end{array}$ & Y & Hennepin & $\begin{array}{l}\text { Medium-density single-family mixed with } \\
\text { high-density multifamily residental area } \\
5 \text { to } 10 \text { years old. Storm sewered with } \\
\text { curb and gutters. Flat with sandy solls. }\end{array}$ \\
\hline $\begin{array}{l}\text { State Highway } 100 \\
\text { storm sewer } \\
\left(0.47 \mathrm{mi}^{2}\right)\end{array}$ & $\mathrm{T}$ & Hennepin & $\begin{array}{l}\text { High-density single family with typical } \\
\text { intersection commercial areas } 20 \text { to } 40 \\
\text { years old. School and major arterial } \\
\text { highway also in drainage. Curb and gut- } \\
\text { ters on gently-sloped loamy soils. Small } \\
\text { holding pond in very upper end. }\end{array}$ \\
\hline $\begin{array}{l}\text { Wesley Park } \\
\text { storm seweई } \\
\quad\left(0.33 \mathrm{mi}^{2}\right)\end{array}$ & W & Hennepin & $\begin{array}{l}\text { Medium-density single family } 10 \text { to } 30 \\
\text { years old with park in lower end. Partly } \\
\text { curbed and guttered on moderately sloped } \\
\text { loamy soils. }\end{array}$ \\
\hline $\begin{array}{l}\text { Sandburg Road } \\
\text { storm sewe } \\
\left(0.12 \mathrm{mi}^{2}\right)\end{array}$ & $\mathrm{Z}$ & Hennepin & $\begin{array}{l}\text { Light industrial park } 1 \text { to } 20 \text { years old. } \\
\text { Partly curbed or guttered. School and } \\
\text { major industry parking lot in upper end } \\
\text { of drainage. Moderately sloped loamy } \\
\text { solls. }\end{array}$ \\
\hline $\begin{array}{l}\text { PDQ-Valley View } \\
\text { Road storm sewer } \\
\quad\left(0.13 \mathrm{mi}^{2}\right)\end{array}$ & Q & Hennepin & $\begin{array}{l}\text { Mixed medium-density single and multi- } \\
\text { family } 1 \text { to } 10 \text { years old. Streets drain } \\
\text { into grass swales before entering storm } \\
\text { sewer. Moderately sloped sandy-loam } \\
\text { solls. }\end{array}$ \\
\hline $\begin{array}{l}\text { Iverson Avenue } \\
\text { storm sewer } \\
\left(0.15 \mathrm{mi}^{2}\right)\end{array}$ & $I$ & Washington & $\begin{array}{l}\text { Medium to high-density single-family } \\
\text { residential presently under construction. } \\
\text { Curbed and guttered. Gently sloped loamy } \\
\text { soils. }\end{array}$ \\
\hline
\end{tabular}




\section{Data Collection and Instrumentation}

Data-collection needs and, hence, instrumentation needs are geared principally towards the hydrologic response of each site. The seven urban storm-sewer sites will undoubtedly be the quickest to respond to rainfall. Each of these seven sites are equipped with an automatic sampler (sampling at 5- to 15-minute intervals) and recording flow and rainfall gages (5minute intervals). The two flashier main stem urban sites (Shingle and Bassett Creeks) are equipped with an automatic sampler (15- to 60-minute intervals) and a flow-recording gage (15-minute interval). The 80th Street storm sewer (Cottage Grove) has a flow-recording gage (5-minute interval), and the Purgatory Creek site has a staff gage (a flow-recording gage located about 2 miles downstream will be used for flow correlation). The latter two urban sites will be sampled by hand.

Each of the six agricultural sites have a flow-recording gage (15-minute interval), five (excluding Carver Creek) have recording rainfall gages (5minute interval), and three (Bevens, Elm, and South Fork Vermililion) have automatic samplers (15- to 60-minute intervals). The other three will be sampled by hand.

Table 3 summarizes the approximate frequency of runoff-sample collection for each group of sites, during both storms and baseflow.

Figures 5 through 12 show the equipment to be used and how it is to be interfaced. All runoff samples collected manually and automatically from baseflow and storms) will be brought to the MWCC laboratory at the Metropolitan Wastewater Treatment Plant. Here, samples will be selected for laboratory preparation, including measurement of specific conductance and $\mathrm{pH}$, subsampling, filtering, preservation, settling, and compositing before being submitted to appropriate MWCC lab groups for analysis. Rainfall samples (wet and dry) and quality-assurance samples will be sent to the Geological Survey central laboratory in Atlanta, Ga., for analysis.

\section{Laboratory Analyses}

Table 4 sumarizes the generalized laboratory-analysis schedules designed for this study. The frequency of analyses will decrease from schedule 1 (three to eight samples per storm) to schedule 4 (one sample every third storm). The schedules were prioritized on the basis of data needs and on laboratory costs. Considerable feedback was obtained from the 208 Technical Advisory Group and from Survey personnel outside the Minnesota District. Laboratory analyses for the two main stem sites on the Minnesota River will be the same as urban-site laboratory schedules 1 and 2, with additional analyses for fecal Streptococci and total organic carbon.

Rainfall samples (wet and dry) will be analyzed for specific conductance, $\mathrm{pH}$, total phosphorus, total nitrite plus nitrate-nitrogen, total ammonia plus organic nitrogen, total lead, sulfate, and chloride. Rainfall sample collection will depend on rainfall magnitude and frequency, probably after an accumulated rainfall of 0.5 inch or after each rain in excess of 0.5 inch. 
Table 3.--Frequency of analyses of runoff samples

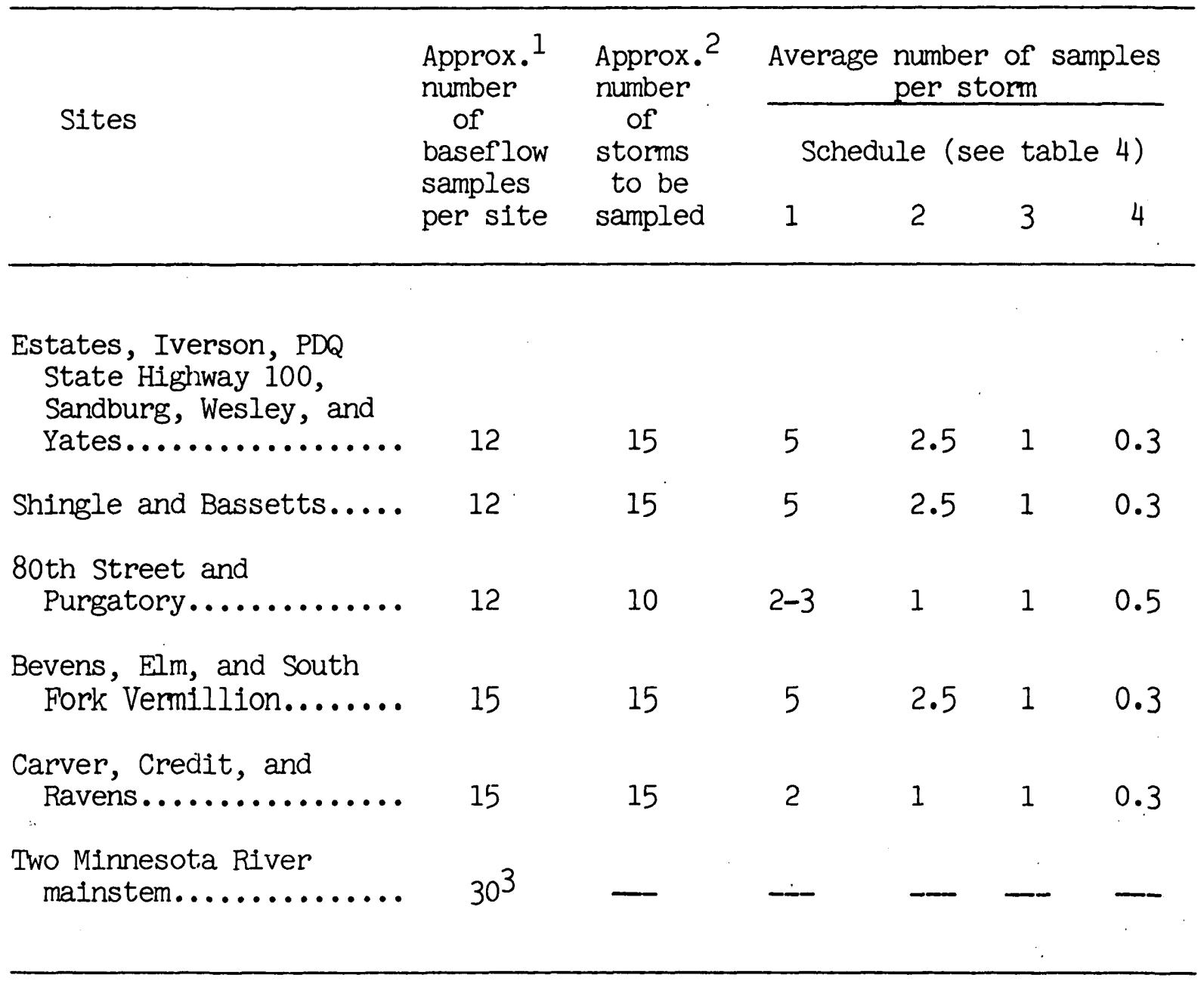

${ }^{1}$ Only Estates, State Highway 100, and Wesley have sustained baseflow; Iverson, $P D Q$, Sandburg, Yates, and 80th Street will be sampled much less frequently.

${ }^{2}$ An equivalence of about 75 percent of these storms will be sampled on a descrete basis, 20 percent will be snowmelt samples, and 5 percent will be storm-composite samples.

3 Will be sampled once a week March through July or August, then about once every 3 to 4 weeks until December 1980. 
Table 4.--Generalized laboratory schedules

Schedule 1

Schedule 2

Schedule 3

Schedule 4

$\begin{array}{llll}\text { Susp. solids } & \text { Diss. solids } & \text { Volatile susp. } & \text { Diss. COD } \\ \text { Diss. phosphorus } & \text { Diss. } \mathrm{NH}_{4} \text { +org. } \mathrm{N} & \text { solids } & \text { Total carbonaceous } \\ \text { Diss. } \mathrm{NO}_{2}+\mathrm{NO}_{3}-\mathrm{N} & \text { Diss. chloride } & \text { Diss. org. } \mathrm{C} & \text { BOD - ultimate } \\ \text { Diss. } \mathrm{NH}_{4}-\mathrm{N} & \text { Total carbonaceous } & \text { Total org. C } & \text { Oil and grease } \\ \text { Total phosphorus } & \text { BOD - 5 day } & \text { Total cadmium. } & \text { PCB's } \\ \text { Total. } \mathrm{NH}_{4} \text { torg.-N } & \text { Fecal coliform } & \text { Total chromium } & \text { Pesticide scan } \\ \text { Total COD } & \text { *Susp. solids }<4 \mathrm{u} & \text { Total copper } & \text { Particle size } \\ \text { Total lead } & \text { *Phosphorus<4u } & \text { Total iron } & \\ & \text { * } \mathrm{NH}_{4} \text { torg. }-\mathrm{N}<4 \mathrm{u} & \text { Total manganese } & \\ & & \text { Total nickel } & \\ & & \text { Total zinc }\end{array}$

AGRICULTURAL SITES

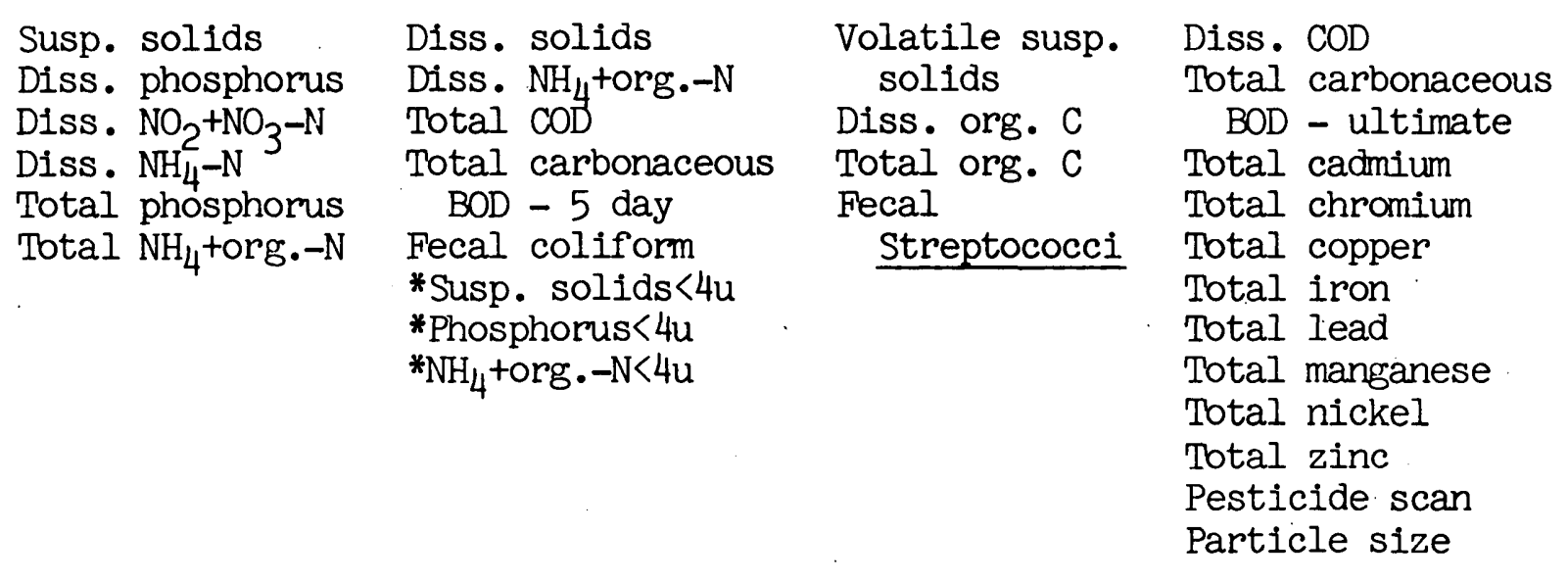

* Samples will be allowed to settle before subsampling and analysis. The 4-micron fall-diameter is temperature and depth dependent but is approximately 61 minutes for a 5-centimeter depth at $20^{\circ} \mathrm{C}$. 


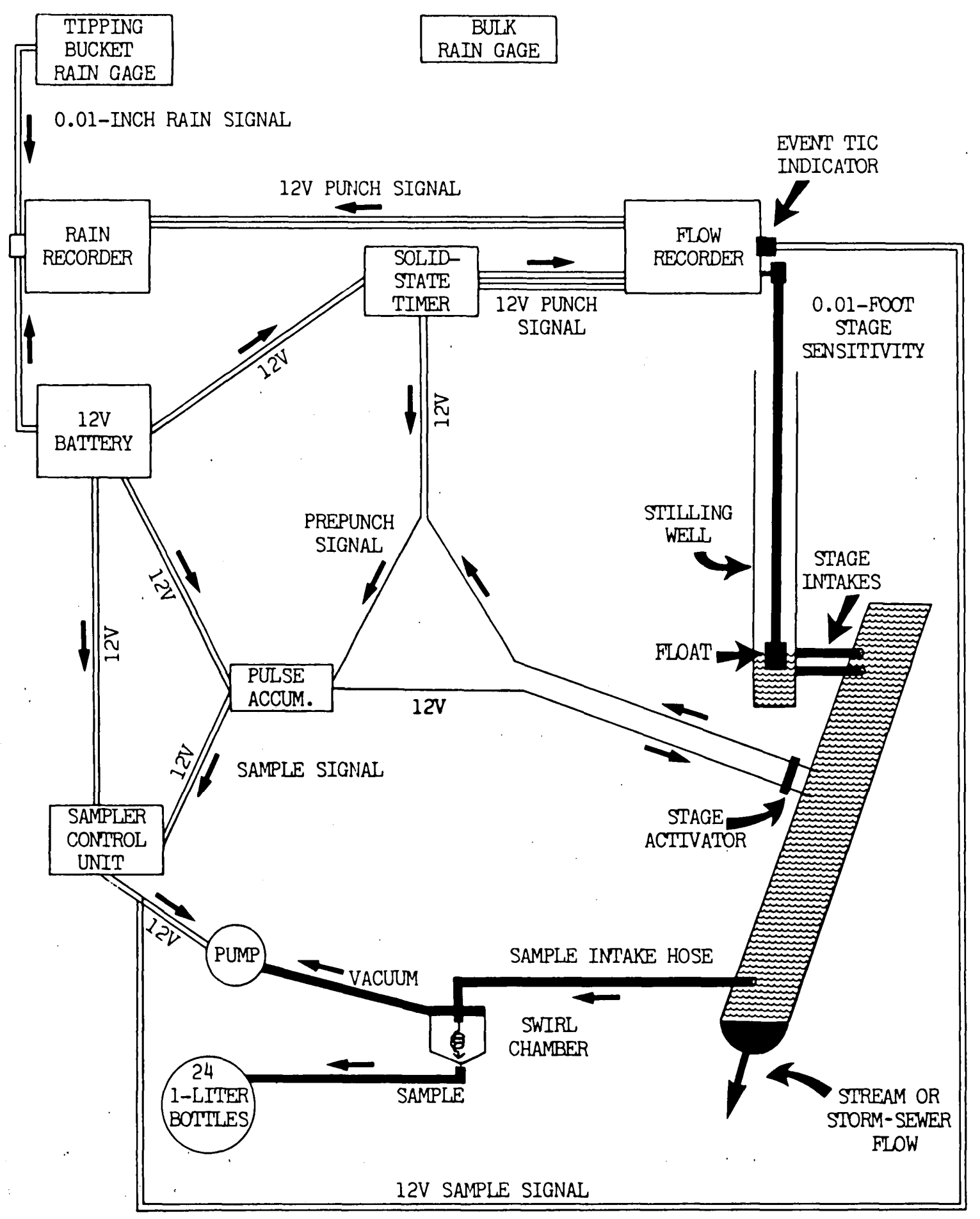

Figure 5.--Diagram of an assombled monitoring station for the Twin Citles runoff study 


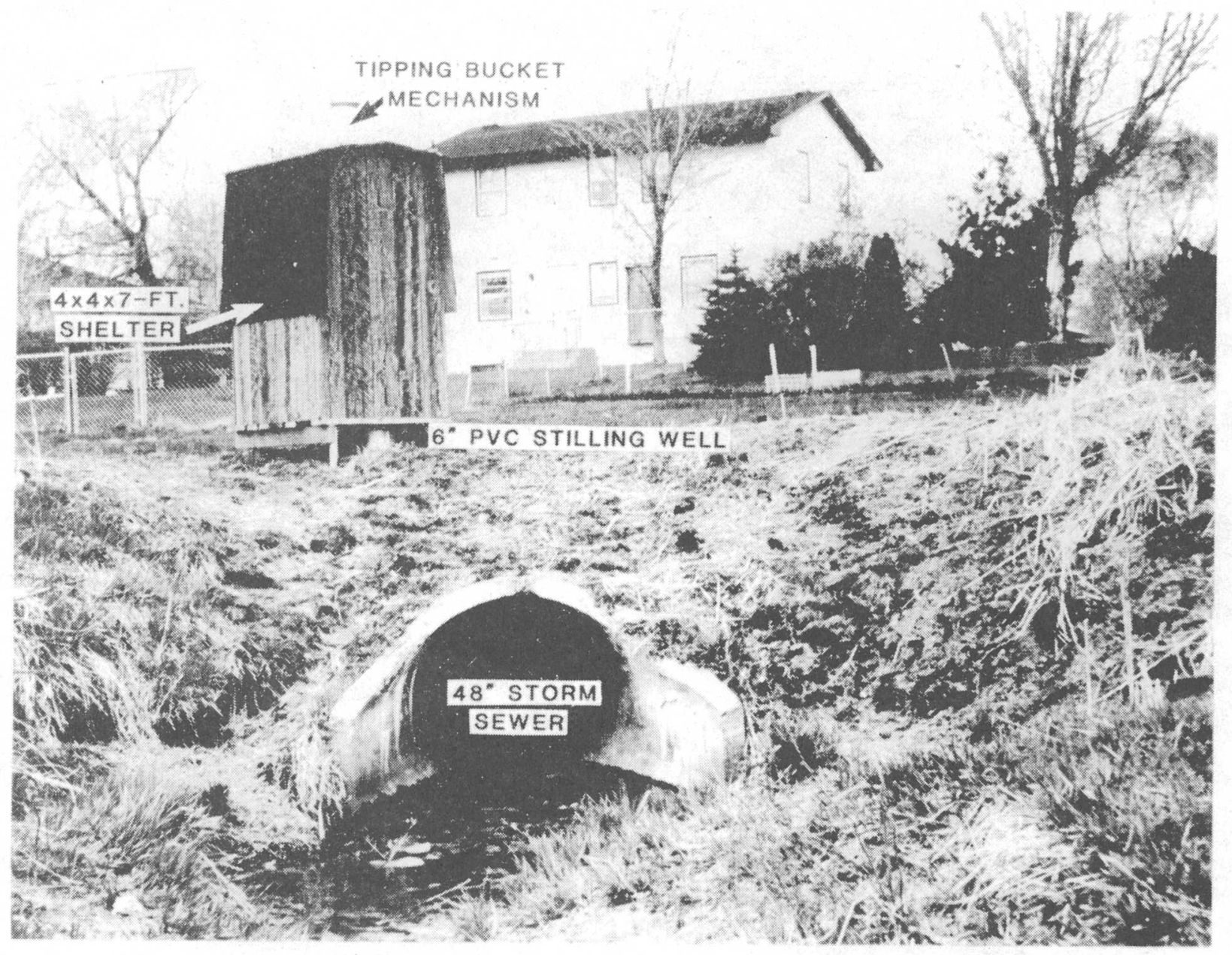

Flgure 6.--Estates Drive gage typlcal of the seven storm sewer Installatlons. The connection between stlling well and storm sewer is made with 3/4-inch galvanized pipe. Only two of the seven gages are located this close to the storm sewer outlet 


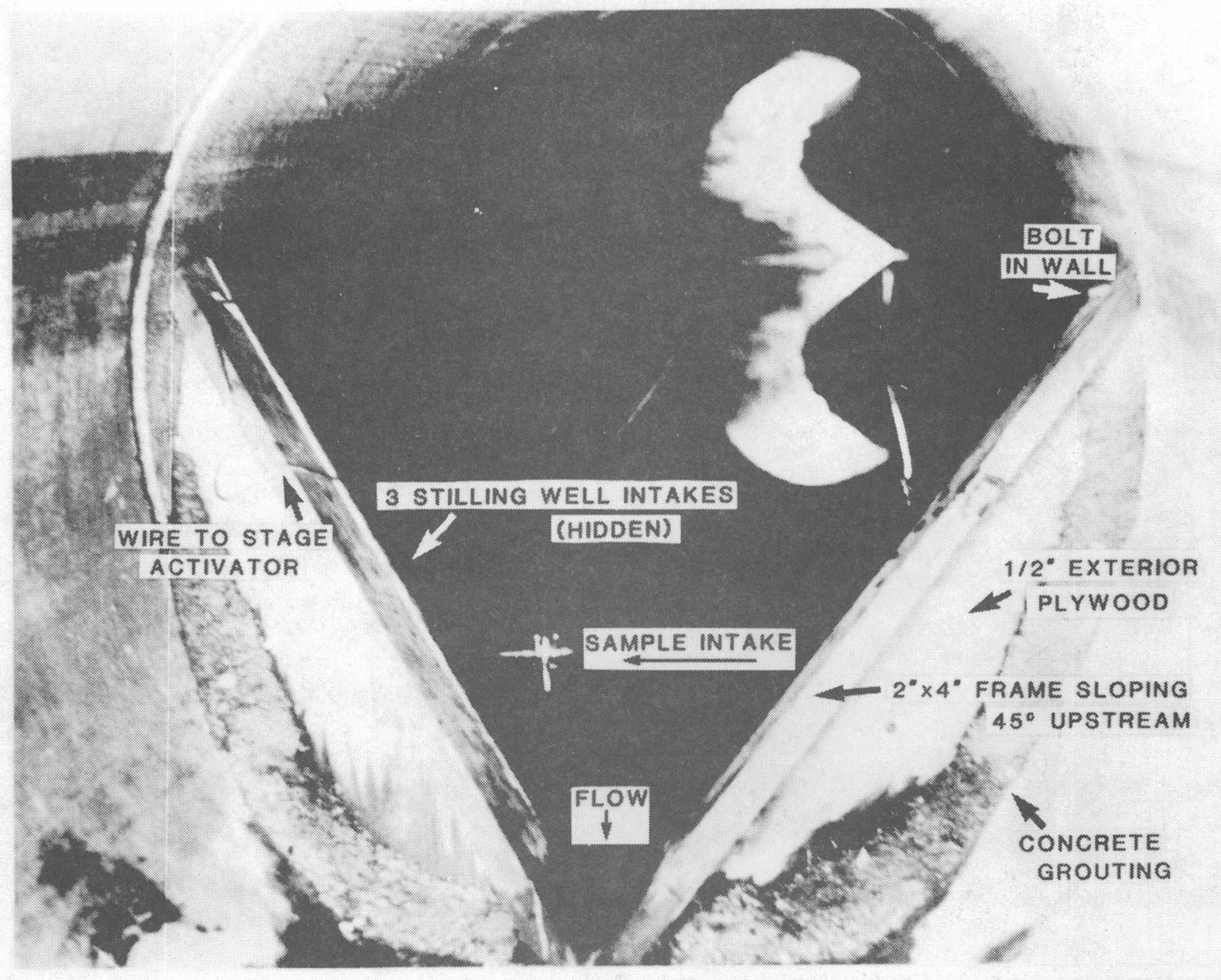

Flgure 7.--Looking upstream at a typical storm-sewer flume (Estates Drive) 


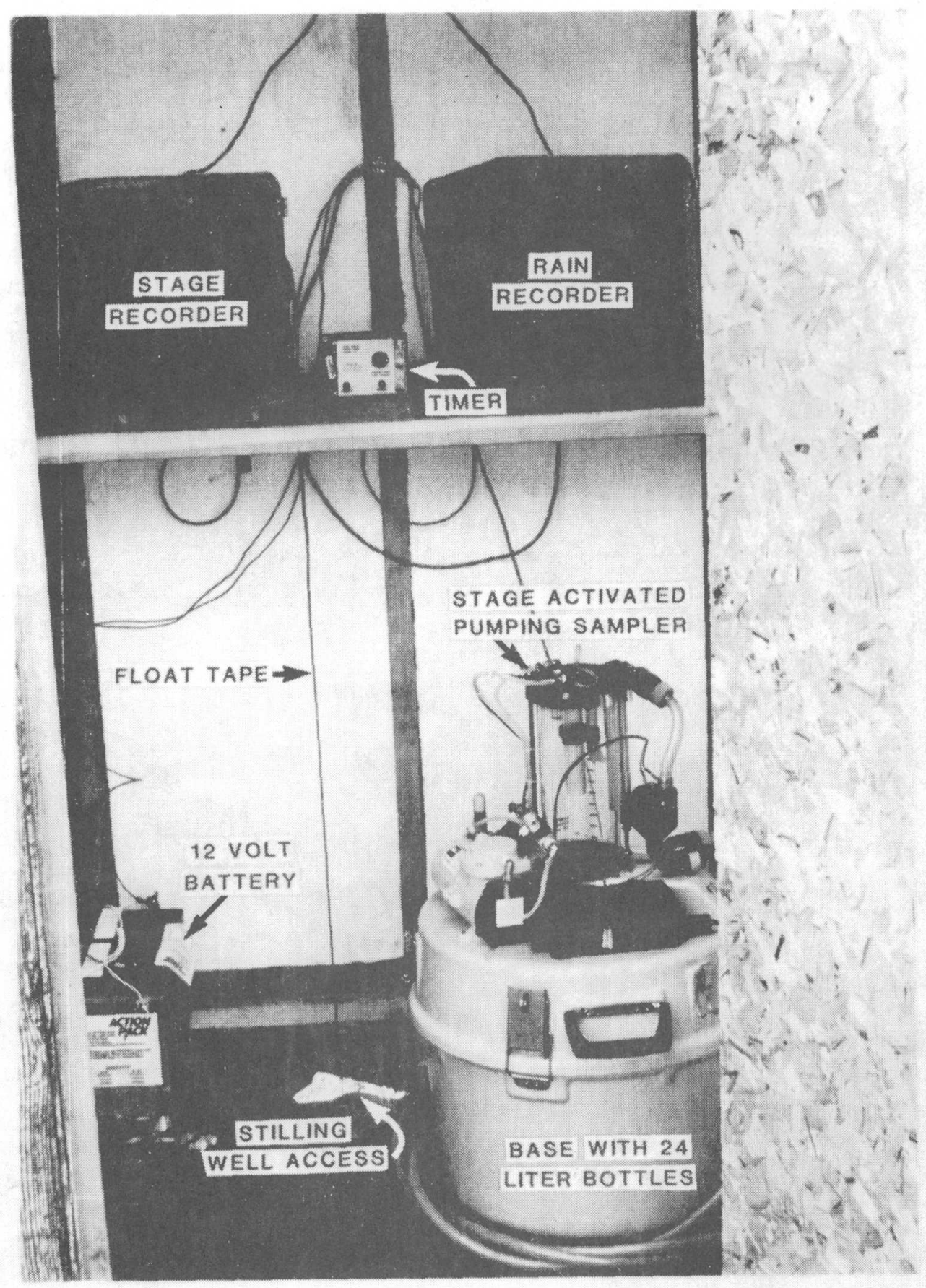

Figure 8.--Inside a typical gaging shelter (tipping bucket rain sensor on roof) 


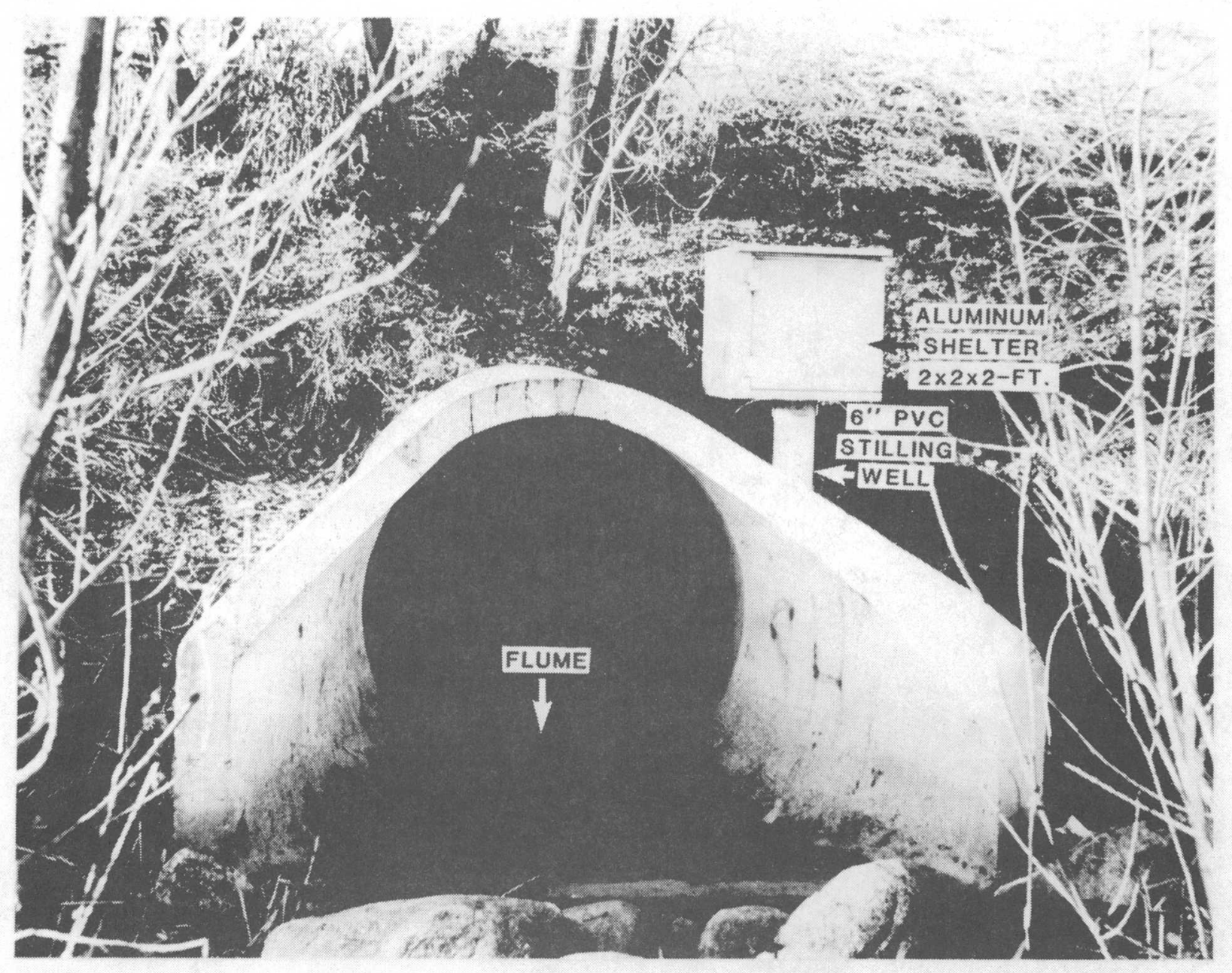

Figure 9.--80th Street storm-sewer gage automated for stage only 


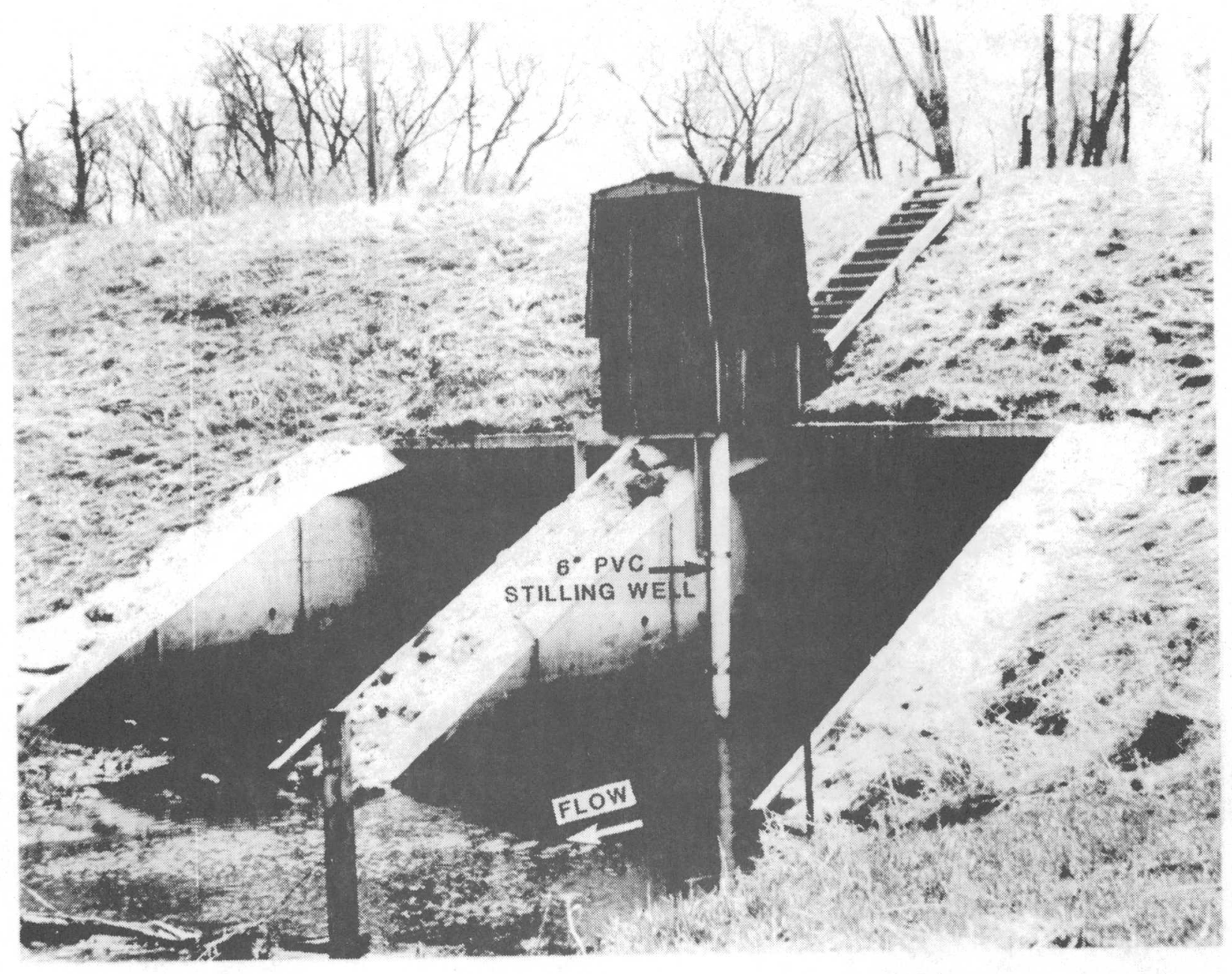

Figure 10.--Elm Creek gage typical of three agricultural and two urban mainstem installations, automated for stage and water sample collection. Only two of these have tipping bucket raingages 


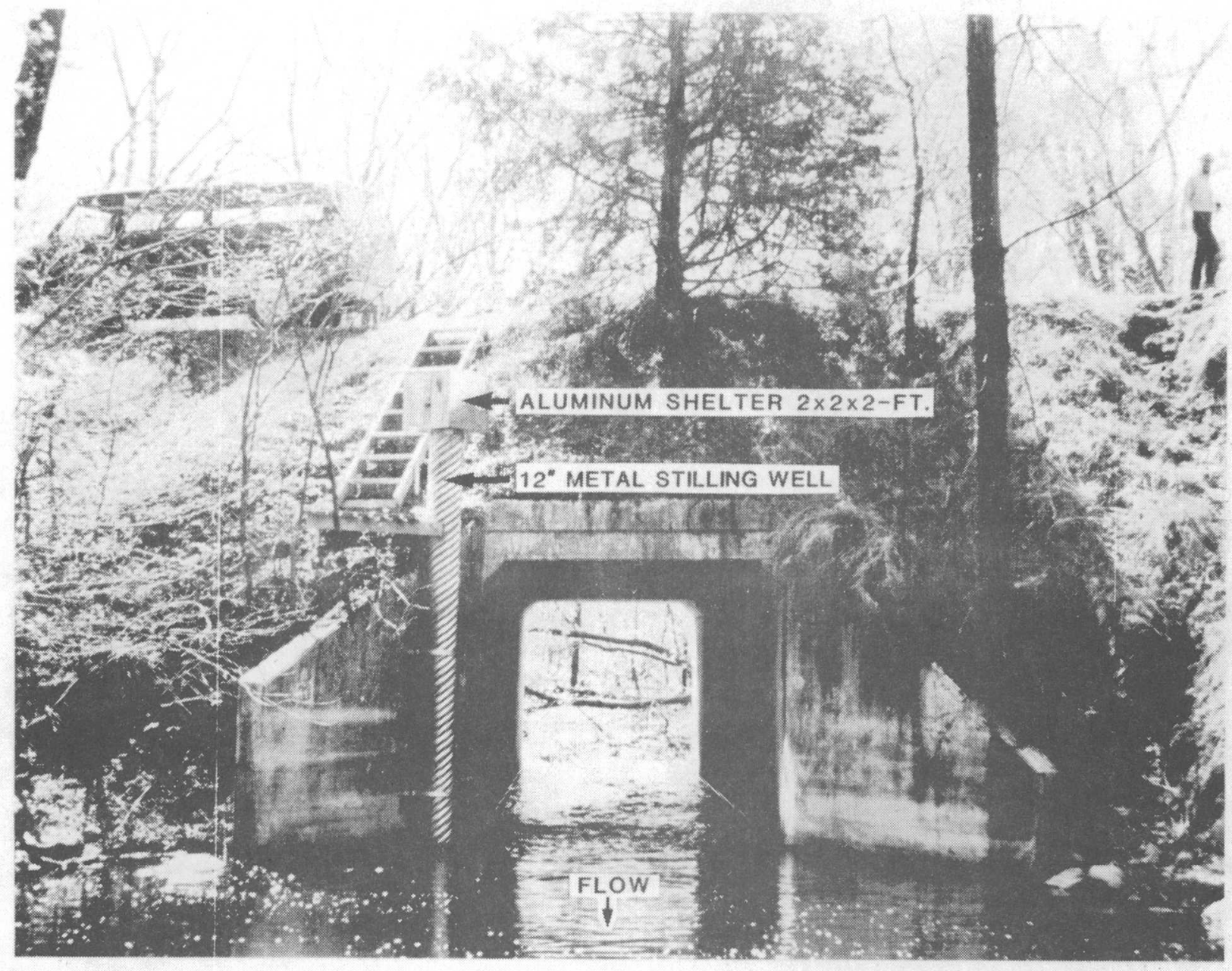

Figure 11.--Credit River gage typical of three agricultural mainstem installations automated for stage only 


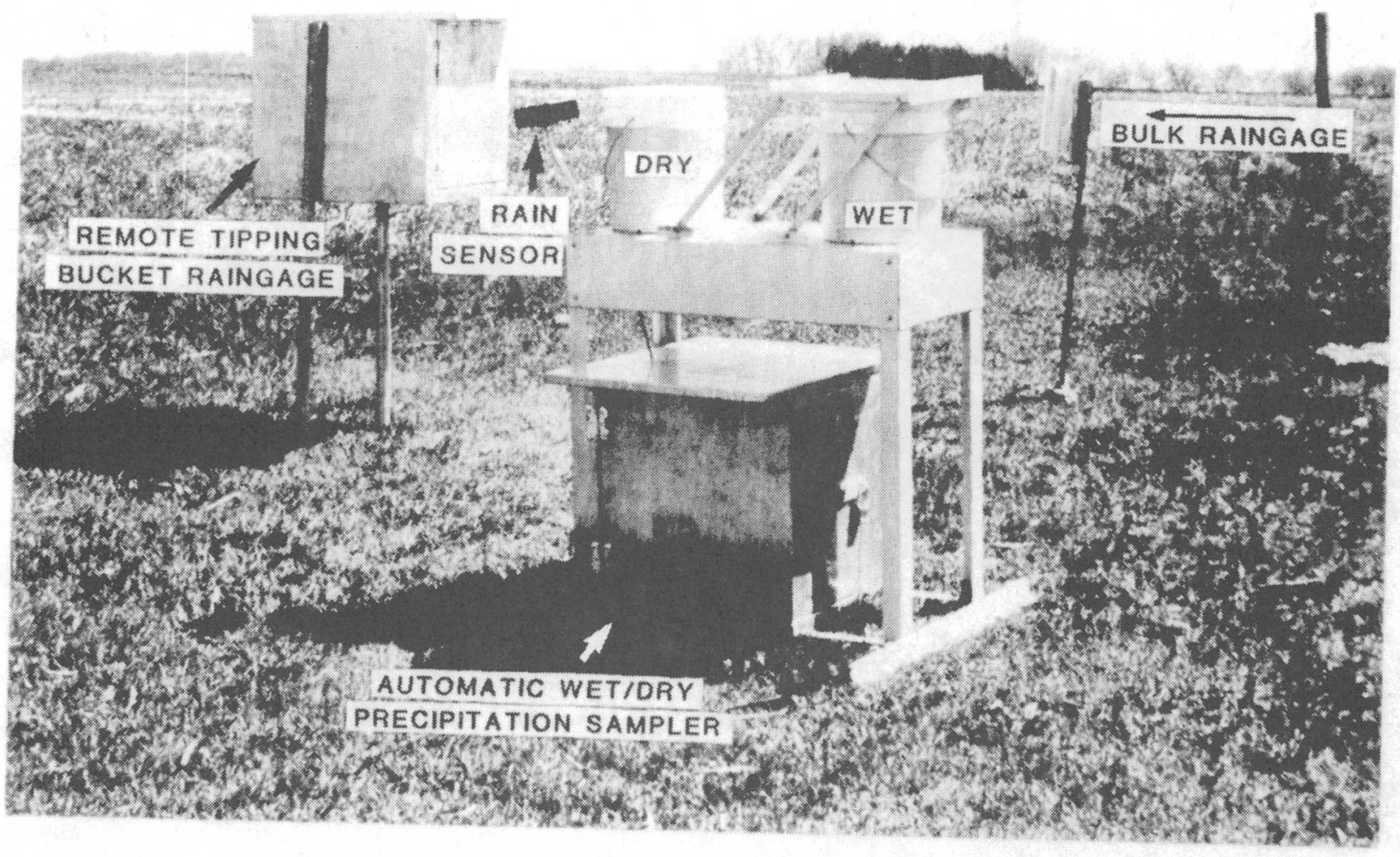

Figure 12.--Bevins Creek automatic wet/dry precipitation installation located with bulk and tipping bucket rain gages in this case 


\section{Quality-Assurance Program}

A quality-assurance program is needed to insure that the data are reliable and suitable for the intended uses. Random errors are associated with analytical procedures, while error bias may result from sampling and subsampling problems, and from mistakes in data compilation and reduction. The purpose of a quality-assurance program then, is to define the amount of error associated with each source in order to establish the confidence limits of the data produced by the study.

Errors associated with data compilation and reduction, usually miscalculations, misplaced decimals, coding and keypunch errors, and machine errors, will be minimized through constant checking and rechecking during each step. Sampling, subsampling, and analytical errors can be minimized by consistent use of tried and true procedures, but errors can never be eliminated.

For this study, samples collected by hand by the most accurate procedure, depth integration, will be used to check the representativeness of samples collected automatically over the full range of flow conditions. The samples collected by hand also will provide the necessary volume for split and replicate samples for other quality checks.

One sample per site will be collected by hand during 10 of the storms that are expected during the study. This sampling will represent about 13 percent of the total number of samples to be analyzed. Samples collected by hand for half the storms will be split by a pour-through cone splitter (a device developed for Geological Survey Urban Hydrology Studies Program). One split sample will be analyzed by the Survey laboratory and the other by MWCC laboratory as a check on analytical procedures. Additional data on the accuracy of analytical procedures will be provided by routine in-house quality-assurance tests such as replicates, spikes, and blind standards in both laboratories.

The other half of the storm samples collected by hand will be collected in a time-synchronized manner similar to that done by the automatic samplers. Both time-synchronized samples will be analyzed by the Survey laboratory as a check on the representativeness of samples collected by the automatic samplers. Triplicate samples will be collected by hand at least three times at an urban and an agricultural site and analyzed by the Survey to gain information on the combined error of the sampling procedure and the short-term variability in each system sampled.

The subsampling procedure may account for a sizable part of the error often associated with analyses of split samples. Therefore, early in the project, five subsample replicates will be submitted to each laboratory for each of four large-volume samples. (or storm-composite samples) that were collected manually from two urban and two agricultural sites. The results of these analyses will indicate whether tests should be repeated. 
Table 5 outlines the number of samples to be analyzed for each test proccdure and laboratory schedule. Because of the reconnaissance nature of the data collection for urban and agricultural schedules 3 and 4 (table 4), the qua].ity-control checks for these constituents will be limited to a single set of manual samples at the urban sites for one storm (urban 3 in table 5).

Table 5.--Quality-assurance program

\begin{tabular}{|c|c|c|c|c|c|c|c|}
\hline \multirow[t]{2}{*}{$\begin{array}{l}\text { Laboratory } \\
\text { schedule }\end{array}$} & \multirow{2}{*}{$\begin{array}{l}\text { Number } \\
\text { storms } \\
\text { per } \\
\text { schedule }\end{array}$} & \multirow{2}{*}{$\begin{array}{l}\text { USGS } \\
\text { part of } \\
\text { manual } \\
\text { splits }\end{array}$} & \multicolumn{2}{|c|}{$\begin{array}{l}\text { Time- } \\
\text { synched }\end{array}$} & \multirow{2}{*}{$\begin{array}{l}\text { Fxtra } \\
\text { manual } \\
\text { triplicates }\end{array}$} & \multirow{2}{*}{$\begin{array}{l}\text { Fixtra } \\
\text { subsample } \\
\text { replicates }\end{array}$} & \multirow[t]{2}{*}{ Total } \\
\hline & & & manual & auto & & & \\
\hline \multirow[t]{2}{*}{ Urban } & 10 & 45 & 45 & 45 & 6 & 6 & 147 \\
\hline & 4 & 18 & 18 & 18 & 6 & 6 & 66 \\
\hline 3 & 1 & 9 & - & 9 & 4 & 6 & 28 \\
\hline \multirow[t]{2}{*}{ Agri. } & 10 & 30 & 15 & 15 & 6 & 6 & 72 \\
\hline & 4 & 12 & 6 & 6 & 6 & 6 & $36:$ \\
\hline
\end{tabular}

Maximum number of samples to be analyzed: 219

Data Management and Analyses

As the MWCC is not set up for computerized laboratory data output, a series of laboratory forms were prepared to serve as the laboratory inventory, and keypunch-coding forms from each of the functional laboratory groups at MWCC (nutrients, metals, biological, and solids). The forms will expedite the input of data into the Survey WATSTORE file and enable the MWCC 1aboratory to provide turnaround in 2 to 3 weeks. 
As the data forms are received from the MWCC laboratory, the data will be keypunched, placed into a temporary file, and then checked against the original forms for accuracy. The runoff-quality data can then be entered into WATSTORE. Data on rainfall quality will be entered directly into WATSTORE by the Survey laboratory. A data-management system, to be available August 1980 through the combined efforts of the Geological Survey Gulf Coast Hydroscience Center and the Geological Survey Urban Hydrology Studies Program, will be used to process all data through the steps outlined in figure 13.

Stage and accumulated rainfall data recorded on paper tape (fig. 13) will be converted to instantaneous discharge and incremental-rainfall data and will be stored in WATSTORE.

The pertinent data in WATSTORE will then be retrieved and placed in the users data file for use in load calculations, generation of tables, data plotting, and correlation analyses. Once the data are put into the desired form, additional analysis will include:

1. The development of regression equations to predict concentrations of water-quality constituents at each site with time and discharge. Those equations with acceptable standard errors $( \pm .30$ percent or less) will be used to estimate concentrations and loads for unsampled periods of recorded flow.

2. Investigation of the similarities and differences in the hydrologic characteristics such as peak flow and stormflow volumes and hydrologic response (table 6 ). Regression equations will be developed for predicting these characteristics from independent variables such as percentage of impervious area, storm characteristics, and antecedent precipitation indices (table 6).

3. Computation of storm loads for all sites for major constituents of interest (schedules 1 and 2 in table 4 ).

4. Determination of the relationship of average storm concentration and storm load of constituents to hydrologic response, stormflow volume, and rainfall volume for each watershed. Group similar sites. Develop regression equations for each site or groups of similar sites to predict storm loadings of major constituents from storm precipitation, antecedent precipitation indices, and other source-related factors (table 6). Regression equations are then used to simulate a long period of storm loads using long-term precipitation records.

5. Computation of long-term average seasonal and annual loads for all sites or groupings for major constituents.

6. Development of regression equations for seasonal and annual loadings of major constituents with variables in table 6 for ail land-use categories in order to estimate loadings for unsampled metropolitan area watersheds. 
Table 6.--List of potential variables to be used in correlation and regression analyses

WATERSHED PARAMEIERS

1. Total drainage areas, in square miles.

2. Contributing drainage area, in square miles. Total area less areas draining into impoundments with no outlet.

3. Impervious area in percent of drainage area.

4. Effective impervious area, in percent of drainage area. Include only impervious surfaces connected directly to a sewer pipe or principal conveyance.

5. Average basin slope, in feet per mile, determined from an average of terrain slopes at 50 or more equispaced points using best available topographic map.

6. Main conveyance slope, in feet per mile, measured at points 10 and 85 percent of the distance from the gaging station to the divide.

7. Permeability of the A horizon of the soil profile, in inches per hour.

8. Available water capacity as an average of the A, B, C soil horizons, in inches of water per inch of soil.

9. Soli-water $\mathrm{pH}$ of the "A" horizon (in $\mathrm{H}_{2} \mathrm{O}$ ).

10. Hydrologic soll group $\left(A, B, C_{2}\right.$, or $\left.D\right)$ according to SCS methodology.

11. Population density, in persons per square mile.

12. Street density, in miles per square mile.

13. Land use of the basins as a percent of drainage area including:

a. Rural and pasture

b. Agricultural

c. Single-family residential

d. Multiple-family residential

e. Commercial

f. Industrial

g. Under construction (bare surface)

h. Idle or vacant land

i. Wetland

j. Parkland

14. Dentention storage, in acre-feet per acre.

15. Drainage density, in miles per square mile.

16. Percent of area storm sewered

17. Percent of streets with curb and gutter drainage.

18. Percent of streets with ditch and swale drainage. 
Table 6.--List of potential variables to be used in correlation and regression analyses--Continued

HYDROLOGIC PARAMETERS

1. Total rainfall, average for the basin in inches.

2. Maximum 5-minute rainfall rate, in inches per hour.

3. Maximum 15-minute rainfall rate, in inches per hour.

4. Maximum 1-hour rainfall rate, in inches per hour.

5. Number of dry days prior to storm, counting backwards to day with greater than 0.2 inches.

6. Number of dry days to storm, in which 0.5 inches of rain fell.

7. Depth of rainfall accummulated during previous day, in inches.

8. Depth of rainfall accummulated during previous 3 days, in inches.

9. Depth of rainfall accummulated during previous 7 days, in inches.

10. Total munoff, in inches, over the basin.

11. Peak discharge, in cubic feet per second.

12. Base flow prior to storm, in cubic feet per second.

13. Duration of storm used to calculate load, in minutes.

14. Time from beginning of rainfall to hydrograph peak, in minutes.

15. Storm-runoff loads of individual constituents, in pounds per acre.

16. Dryfall load of individual constituents since previous storm sampled, in pounds per acre.

17. Wetfall load of individual constituents since previous storm sampled, in pounds per acre.

18. Snowmelt discharge, in inches over the basin.

19. Snow depth over watershed, in inches.

20. Hydrologic response, which is the stormflow volume expressed as a percent of rainfall volume.

ENVIRONMENTAL PARAMETERS

1. Methods and frequency of street cleaning.

2. Amounts and frequency of chemical fertilizer and pesticides appl1cation. Fertilizers determined in equivalent pounds per acre of nitrogen and phosphorus.

3. Sewer flushing and catch-basin cleaning.

4. Agricultural activities and practices.

5. Construction, excavating, and landscaping activities.

6. Average daily vehicle traffic.

7. Refuse-collection practices.

8. Street salting during icy conditions.

9. Detention storage, including rooftop.

10. Flood retarding features.

11. Solid-waste-disposal practices.

12. Leaf disposal.

13. Identify sediment sources such as road ditches, embankments, and masswasting areas. 


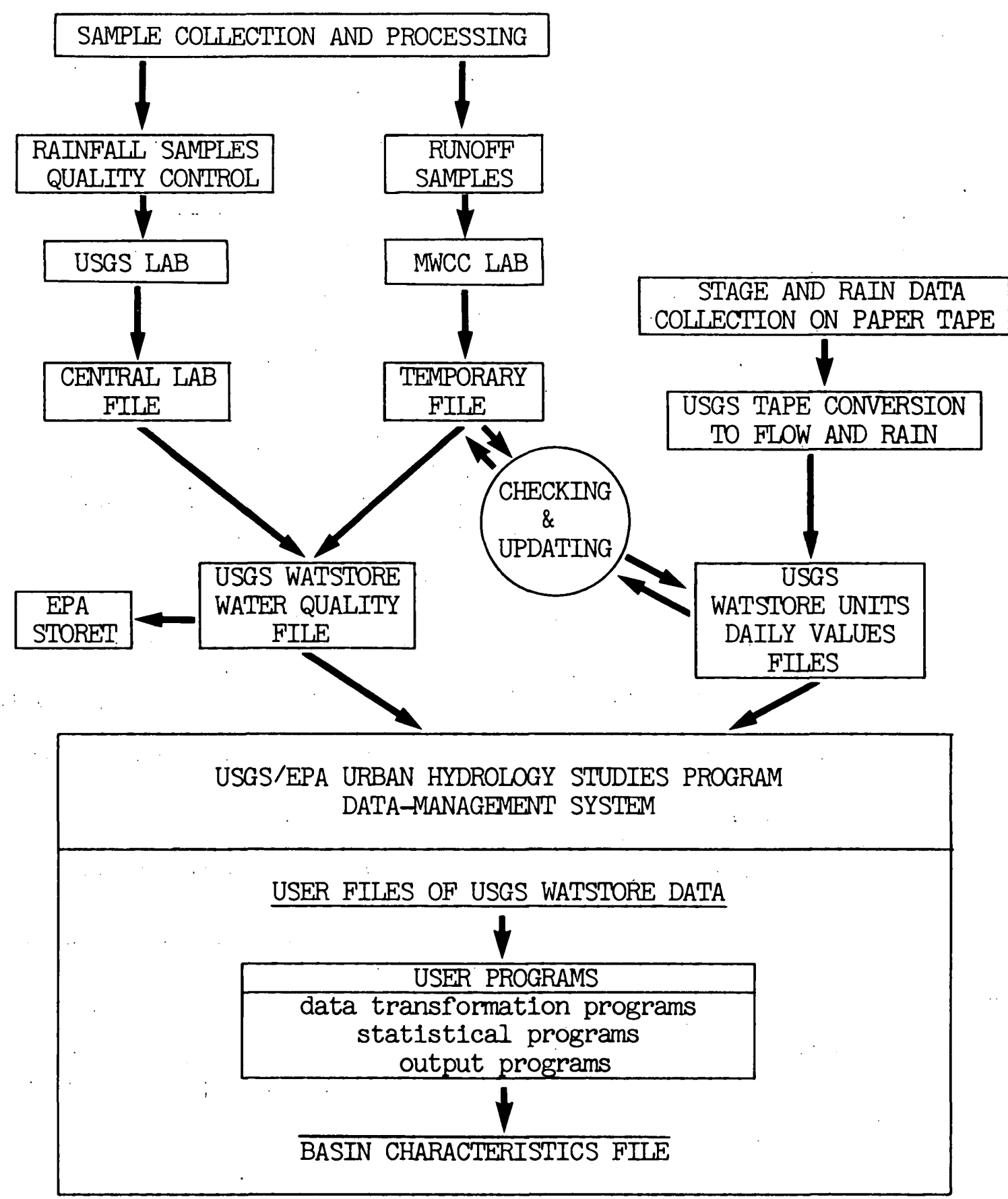

Flgure 13.--Flow chart of data-management processes for the Twin CItles runoff study 
Final Products

All data collected during the study will be published in an open-file report, and analyses of the data will be published in an interpretive report. One or more professional journal reports are also planned.

Time Schedule

\begin{tabular}{lll}
\hline \multicolumn{1}{c}{ Task } & Begin date & End date \\
\hline Site selection & September 1979 & November 1979 \\
Gage construction & September 1979 & March 1980 \\
Equipment installation & January 1980 & March 1980 \\
Data collection, periodic & January 1980 & December 1980 \\
Data collection, snowmelt & January 1980 & March 1980 \\
Data collection, storms & April 1980 & September 1980 \\
Analyze data & March 1980 & December 1980 \\
Statistical analyses & June 1980 & February 1981 \\
Open-file data report & & December 1980 \\
Preliminary interpretive report & & February 1981 \\
Final interpretive report & & May 1981 \\
\hline
\end{tabular}


SUMMARY

A program of water-quality sampling to define the relationships between land use, watershed characteristics, and the quantity, quality, and timing of runoff has been started for the Twin Cities metropolitan area of Minnesota. Ten major watersheds were chosen as representative of conditions in the metropolitan area. Each will be sampled at one location near the outlet. Six of the watersheds are agricultural, and range in size from 14.3 to 82.9 square miles. The four remaining watersheds are urbanized and range in size from 1.22 to 31.7 square miles. In addition, seven urban subwatersheds, which range in size from 0.12 to 0.47 square miles and reflect a dominant land-use type, will also be sampled.

Data collection is designed around the hydrologic conditions expected for each site. Sixteen of 17 sites are instrumented to define stream discharge and 12 sites have automatic water samplers and recording rain gages. In addition, six sites will have automatic wetfall/dryfall precipitation collectors.

Samples for analysis of 32 chemical, physical, and biological constituents will be collected at varying frequencies, with emphasis on storm sampling for suspended solids and nutrients. A data-management system being designed for the U.S. Geological Survey Urban Hydrology Studies Program will facilitate data processing. Data interpretation will be aimed at defining the quantity and quality characteristics of runoff from study watersheds. These findings will be extrapolated to unsampled watersheds in the metropolitan area.

At present; funds are insufficient to carry the sampling into 1981. However, another season of data collection, even at a reduced level, may be highly desirable. 


\section{REFERENCES}

Bradford, W. L., 1977, Urban stormwater pollutant loadings: A statistical summary through 1972: Journal of the Water Pollution Control Federation, v. 49, no. 4, p. 613-622.

Federal Water Pollution Control Administration, 1969, Water pollution aspects of urban runoff: Water Pollution Control Series WP-20-15, 272 p.

Larger, J. A., and Smith, W. G., 1974, Urban storm water management and technology: An assessment: Metcalf \& Eddy, Inc. Rept., Environmental Protection Technology Series EPA 670/2-74-040, 447 p.

McElroy, F. T. R., Mattox, C. F., Hartman, D. W., and Bell, J. M., 1976, Sampling and analysis of storm water runoff from urban and semi-urban/ rural watersheds: Water Resources Research Center, Purdue University Technical Report 64, 102 p.

Oberts, G. L., and Jouseau, M., 1979, Water pollution from non-point sources: An assessment and recommendations: Metropolitan Council of the Twin Cities area, publication no. 62-79-008, 194 p.

Sliter, J. T., 1976, Focusing on nonpoint sources: Journal of the Water Pollution Control Federation, v. 48, no. 1, p. 3-6.

Sonzogni, W. C., Chesters, G., Coote, D. R., Jeffs, D. N., Konrad, J. C., Ostry, R. C., Robinson, J. B., 1980, Pollution from land munoff:

Environmental Science and Technology, v. 14, no. 2 p. 148-153. 